\title{
ZONES AND SEGMENTS AS TAXA USED \\ IN THE HIERARCHICAL CLASSIFICATION OF RIVERINE LANDSCAPES: A CASE STUDY OF THE SMREC̆IANKA BROOK, SLOVAK REPUBLIC
}

\author{
Ivana TOMČ́́KOVÁ
}

\begin{abstract}
A river is a highly complex structure and the constituent of landscape and catchment basin from which it drains water. In the holistic concept, a river is defined in mutual interactions with its surroundings as a spatial system - the riverine landscape. As a product of fluvial processes, the riverine landscape has a regular spatial hierarchical structure, which is determined by the structure of its morphology, substrate, biota, land cover and socioeconomic structures. The aim of this paper is to verify the river landscape hierarchical classification and to identify the so-called higher taxa - zones and segments in the Smrečianka valley. The main data sources were hydrological maps at 1:50 000, topographic maps at 1:10 000 and 1:25 000, GIS database levels, geological maps at 1:50 000, and the boundaries were specified by a field survey.
\end{abstract}

\section{Shrnutí}

\section{Zóny a segmenty jako taxony v hierarichické klasifikaci říční krajiny: př́ipadová studie - vodní tok Smrečianky, Slovenská republika}

Řeka je složitý systém, součást krajiny a povodí, kterou protéká a ze které odvádí vodu. V holistickém chápání se řeka ve suých vzájemných interakcí se suým okolím definuje jako prostorový systém - ř́ční krajina. Řiční krajinajako produkt fluviálních procesů má zákonitou prostorovou hierarchickou strukturu determinovanou strukturou její morfologie, substrátu, bioty, krajinné pokrývky a socioekonomických struktur. Cílem př́spěvku je charakterizovat hierarchickou klasifikaci ř́ční krajiny a identifikovat tzv. vyšši taxony - zóny a segmenty vodního toku Smrečianky. Základním zdrojem údajü byly vodohospodářské mapy v měř́tku 1:50 000, topografické mapy v měřitku 1:10 000 a 1:25 000, databázové vrstvy GIS, geologické mapy v měř́tku 1:50 000.

Key words: riverine landscape, River Landscape Hierarchical Classification, spatial variability, zone, segment, Smrečianka brook, Slovak Republic

\section{Introduction}

Rivers have always been a strategic phenomenon for humanity. People have always desired to tame the streams and use them as a source of energy, material, food and transport, and to develop the land around them into towns, forests or fields. A river is a complex system, an integral part of the landscape and river basin, from which it drains water. In the holistic perception of the word, river is understood in its mutual interactions with its environment, and it is defined as a spatial system, riverine landscape, a hydro-system. For its complex character, the methodology and methods of hydrology, fluvial geomorphology, hydrobiology, hydroecology, landscape ecology, economy, sociology and legislation are applied, which gives us an appropriate tool for integrated management, protection, or revitalization of the riverine landscape (Lehotský, 2006).

The aim of this report is to verify the riverine landscape hierarchical classification and to identify the so-called higher taxa - zones and segments - in the Smrečianka brook. My main sources were hydrological maps 1:50 000, topographic maps $1: 10000$ and 1:25000, GIS database levels, geological maps 1:50 000, with boundaries specified by a field survey.

\section{Theoretical and methodological bases}

The riverine landscape presents a geographic entity, a taxon of landscape structures, situated in the valley 
bottom, or large-scale landscape depression, which is a 'product' of fluvial processes (Lehotský, 2006). In our understanding, river landscape is not identical with the morphologically perceived type of fluvial relief. It is understood in the narrower sense and represents a relief type, which was formed by the activity of streams along with water-initiated slope processes.

Riverine landscape is a spatial entity, which has been defined not long ago in physical geographic works, or was commonly presented as the lowest, non-structured, homogenous entity within the terrestrial landscape types. Even in the field of landscape ecology, the riverine landscape is presented and perceived as in physical geography or only ecologically, i.e. as a bio-corridor.

According to Lehotský (2005), the riverine landscape has a complex structure and consists of a hydrogeomorphological substrate basis, soil, a lower layer of air, biota and landscape cover structures. In terms of its lateral dimension and generally speaking, a riverine landscape is morphologically differentiated to include the stream channel with its bed and banks, the flood plain and the transitional upland fringe.

With its defined position within the drainage basin, a riverine landscape can be perceived through the optics of hierarchy. As a product of complex processes, it has its regular spatial and hierarchical structure, basically determined by the biophysical pattern as a consequence of climatic and hydrological processes.
A number of hierarchical classifications linking the catchment and channel have been proposed as a tool for effective river investigation and management (Frissell et al., 1986; Rowentree, Wadeson, 1998; Wadeson, Rowentree, 1998; Maddock, 1999; Thomson et al., 2001; Brierley, Fryirs, 2002; Pool, 2002). These works were used as conceptual guidelines for the development of a model of River Landscape Hierarchical Classification (RLHC) according to Lehotský, Grešková (2003), Lehotský (2004), and Kidová, Lehotský (2012). It is structured into seven taxonomies: 1. river/drainage basin; 2. zone; 3 . segment; 4. riverine landscape unit; 5. channel reach; 6. morpho-hydroecological unit; and 7. facies. Every taxon is different from the others with the specific characteristics of landform, its kinds, processes and structures, as well as the structure of other components of the landscape. They are interrelated based on the river continuum in horizontal, as well as in lateral, vertical and time dimensions (Fig. 1).

From the perspective of sustainable water management, its sources and river systems, the term river basin is applied in the natural sciences and technical disciplines as a spatial unit. In the listed hierarchical classification, it represents the highest taxonomic level. From the hydrological point of view, it represents a depression on the Earth's surface, delimitated by the watershed divide and the mouth with the river system, from which water flows into the given profile of one main stream. In geomorphological

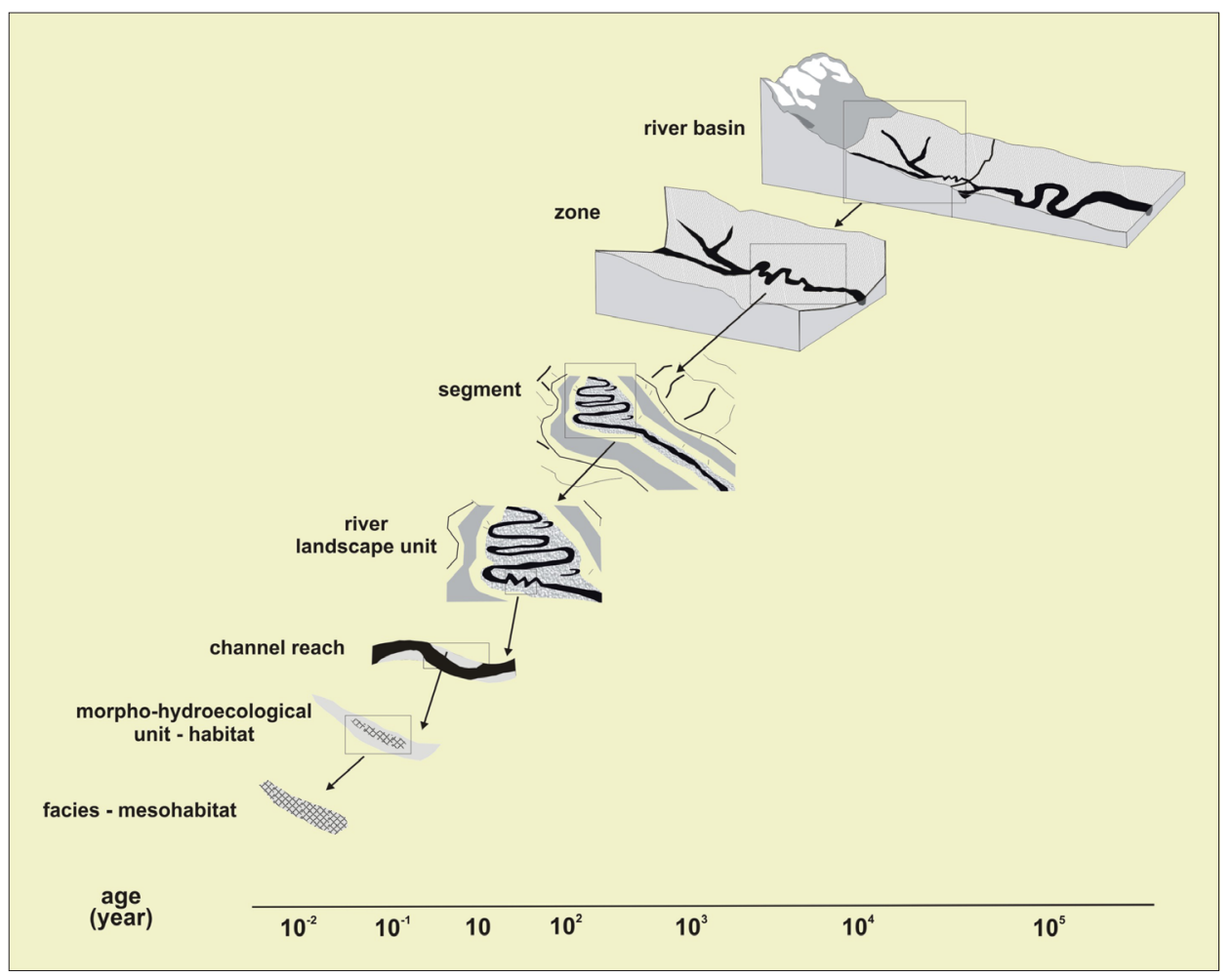

Fig. 1: Riverine Landscape Hierarchical Classification (after Lehotský, 2004, modified) 
terms, it is a depression, a horizontally tilted formation on the Earth's surface, the characteristics of which determine the river system properties.

Higher taxa - zones and segments - within the RLHC generate by their morphotectonic qualities the river's energy character, while by their morphoclimatic and substrate-soil conditions and by the landscape cover, they determine the processes within the drainage basin, i.e. they form the character of lower taxonomic units. The zone and the segment are delimited by the water divide, and by the line running through the lateral valley profile up to reaching the water divide. Morphographic types of ridges and platforms are delimited by the line connecting inflexed points and slope cuts, with the line running through the lateral profile of the valley up to reaching the defined line (Lehotský, Lacika, 2007).

Azone: this represents an area inside the drainage basin, which is homogenous in terms of relief energy, runoff, production of sediments and geology. Fundaments of the zone typology of streams in Slovakia were compiled by Lehotský and Novotný (2004). In their classification, the hierarchically primary criterion was the principle of longitudinal connectivity (Fig. 2). They stem from the concept of three fundamental regimes (activities) of the stream - erosion, transport and accumulation, as according to Schumm (1977), who distinguishes three zones of the river geomorphological continuum:

- Zone 1 - Source (headwaters) Zone (erosion): i.e. spring parts of the drainage basin with rivers up to the $4^{\text {th }}$ order (Strahler, 1957) with the straight simple channel, high flow velocity and beds made of gravel, low temperature and high concentration (repletion) of oxygen. In most cases, these are valleys with the dominating colluvial types of river reaches;

- Zone 2 - Transfer Zone (erosion/deposition): represents relatively broad and shallow segments (brooks, small rivers) with well-oxygenated water, relatively fast currents and higher channel sinuosity; and

- Zone 3 - Depositional/response Zone (deposition): represents downstream sinus reaches of larger rivers with slow currents and with the lower concentration of oxygen, with a high amount of coarse particulate organic material (CPOM).

In the rivers of lower orders or running through mountain landscapes, the deposition zone is confined only to an alluvial fun or confluence environment.

A segment: this is a part of the zone with a quasihomogenous relief type (valley) and a substrate, river network, with an identical amount of water and sediment discharge. It is classified based on the index of sediment/flow discharge, presence of knickpoints along the longitudinal profile, and on the specific river network or tributaries with the drainage area up to $1 / 2$ of the trunk stream drainage basin.

A riverine landscape unit: this is an integrated simple corridor consisting of riverbed, bank, riparian zone, floodplain, upland fringe and aquifer, which is distinguished from the rest of the drainage basin; however, it is well integrated with it. Its boundaries are determined by the river type (channel planform and floodplain width), morphology and ecosystem parameters of the floodplain and its land cover.

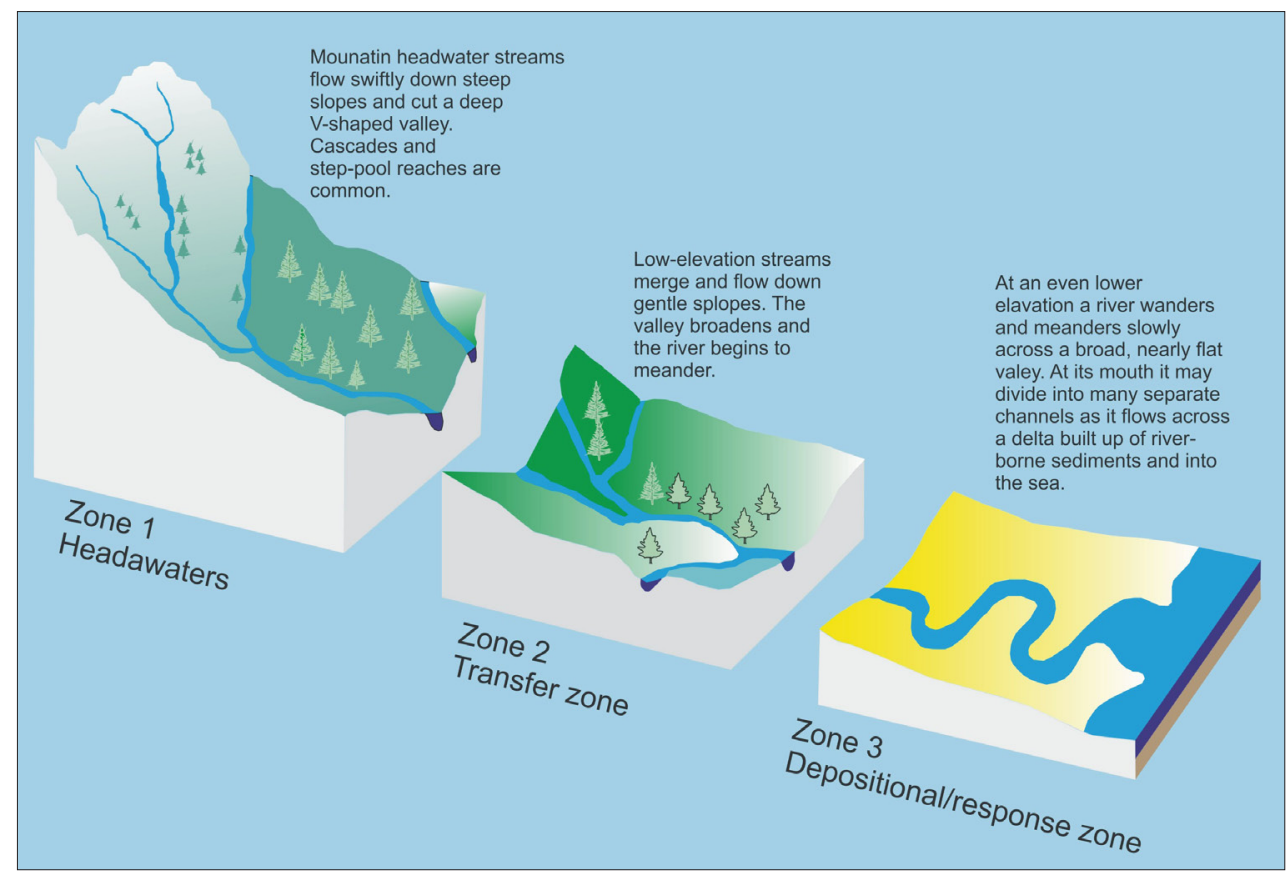

Fig. 2: Three zones within RLHC (Miller, 1990) 
A channel reach: this is a longitudinal part of the channel with the uniform structure of its morphological units, which lead to a typical grouping of geosystems and ecosystems. Their typology is presented in the study by Grešková, Lehotský (2004).

Morpho-hydroecological unit - habitat: this is a fundamental structure of the channel formed by either vertical or lateral channel erosion, or by channel accumulation (sand and gravel bar, etc.), with plants or animals. Boundaries of this taxon are determined by fine geomorphological features.

Habitat unit - mesohabitat: this is the spatially clearly internal riverbed environment. It is determined by temporally variable hydraulic and substrate characteristics, associated with hyporheic flow, different kinds of currents and in-channel and stream plant communities, as well as with the communities of fish and invertebrates.

Every taxon is differentiated from the others by specific relief characteristics, processes and the structure of other riverine landscape components. They are mutually interrelated on the principles of connectivity and the river continuum in longitudinal, lateral, vertical and time dimensions. As opposed to geosystems located in other landscape types (terrestrial), there are more intense taxa relations, greatly influencing characteristics and formation of hierarchically higher or lower taxa. Processes between particular hierarchical levels of a riverine landscape take place both ways (Pool, 2002).

\section{Research Results}

\subsection{Drainage Basin}

The Smrečianka brook is a right-bank tributary of the Váh River. It springs in the Liptov Tatra Mts., the western part of the Tatra Mts., at an altitude of $1,680 \mathrm{~m}$ a.s.l., in a small glacial cirque (kar) on the southern slopes of Plačlivé, between the Žiarske sedlo
Saddle and Smrek, in the northern fork of Baranec, on the north-eastern slopes of the Žiarska dolina Valley. It flows into the Liptov basin, in the part called the Smrečianska Upland and flows into the Váh River in the part called the Liptovská floodplain at $588.2 \mathrm{~m}$ a.s.l. The stream is $18.5 \mathrm{~km}$ long. The studied drainage basin has an elongated, feathery shape. Its main tributary is the Vrbička, which is $3.65 \mathrm{~km}$ long and flows into the Smrečianka in the village of Smrečany (Fig. 3).

\subsection{Zones}

In accordance with Lehotský and Novotný (2004), we distinguish three zones in the drainage basin of the Smrečianka brook: 1. source zone, composed of the Žiarska Valley; 2. transfer zone, covered by the Liptov basin hilly land up to the Podbreziny housing estate area; and 3. response zone, which is spreading from the Podbreziny area up to the confluence of the Smrečianka brook with the Váh River.

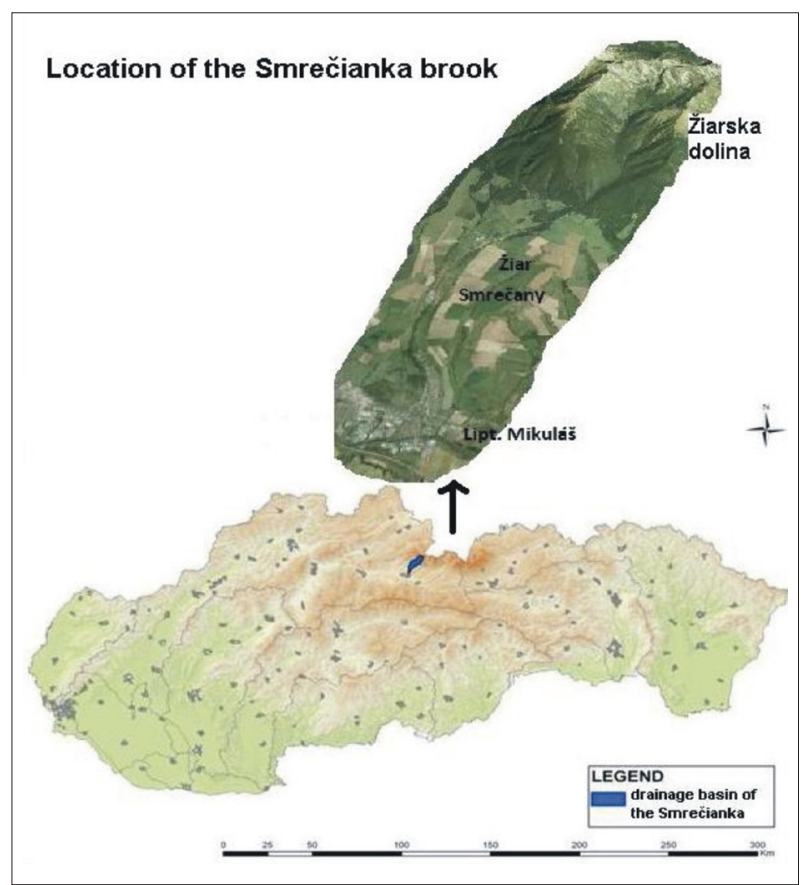

Fig. 3: Location of the Smrečianka brook in Slovakia

\begin{tabular}{|c|c|c|c|c|c|c|c|c|}
\hline \multicolumn{2}{|c|}{$\begin{array}{l}\text { Number and name of } \\
\text { water meter station }\end{array}$} & \multirow[t]{2}{*}{ Stream } & & & & & & \\
\hline \multirow{4}{*}{5530} & \multirow{4}{*}{ Žiarska dolina } & & & $\begin{array}{l}\text { Drainage basin } \\
\text { surface }\left(\mathbf{k m}^{2}\right)\end{array}$ & $\begin{array}{c}\mathbf{H}_{\mathrm{as}} \\
(\mathrm{mm})\end{array}$ & $\begin{array}{l}\text { Outlet } \\
(\mathrm{mm})\end{array}$ & $\begin{array}{l}\text { Losses } \\
(\mathrm{mm})\end{array}$ & $\begin{array}{c}\text { Outlet } \\
\text { coefficient }\end{array}$ \\
\hline & & \multirow{3}{*}{ Smrečianka } & \multirow{3}{*}{$1963-80$} & 17.99 & 1,658 & 1,260 & 398 & 0.76 \\
\hline & & & & 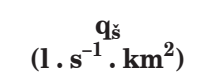 & $\begin{array}{c}\mathbf{Q}_{\mathbf{a}} \\
(\mathrm{m} 3 \cdot \mathrm{s}-1)\end{array}$ & $\underset{\left(\mathbf{m}^{3} \cdot \mathbf{s}^{-1}\right)}{\mathbf{Q}_{\mathrm{rmin}}}$ & $\underset{\left(\mathbf{m}^{3} \cdot \mathbf{s}^{-1}\right)}{\mathbf{Q}_{\mathrm{rmax}}}$ & \\
\hline & & & & 39.91 & 0.718 & 0.571 & 1.178 & \\
\hline
\end{tabular}

Tab. 1: Some hydrographic and hydrological characteristics of the Smrečianka brook. Source: Adámyová,1989 
The source (headwaters) zone (A) has a valley character. It is a zone with a high degree of gradient and stream energy. The Smrečianka brook channel has a steep slope (ca. 10\%). In the source part, speaking in morphological terms, the riverine landscape consists only of the channel and adjacent slopes, the character of which is mainly determined by the morphometric character of slopes and substrate, vertical stream erosion and material delivery, with the domination of the colluvial type of river reaches. In the central part of the zone, the channel material is composed of boulders, which are structured in step-pool channel morphology. At a number of spots, especially with the moraine deposition, we can find channel reaches of boulder/block morphology type, which is typical for streams with boulder-formed riverbeds and boulders emerging from the riverbed. The down-stream material is differentiated and the particle-size of bed material is diminishing and poorly sorted. The valley is "V" shaped. At the valley mouth, the morphological basis of the riverine landscape in the valley is the crosssection, in spite of its low width composed of three main morphologically distinct levels (floodplain, 2-3 low
Holocene terraces and narrow colluvial upland fringe). The floodplain is characterized by high energy, mostly built of non-cohesive coarse-grained material. The channel has a gentler slope and increased index of sinuosity. Some river reaches exhibit stream braiding, which gives rise to a system of multiple, seasonally active, meandering channels separated from one another by islands. These are covered by shrubs and trees, namely by spruce, pine, birch and willow.

The transfer zone $(B)$ is localized in the Liptov Basin hilly-land. Its valley shape represents a broad "U". The channel planform downstream is changing from a single thread channel to a relatively narrow braided one. Dominant channel morphological features are bar structures alternated by plane bed channel morphology. However, almost one half of the length of the stream is channelized. The floodplain is wide, with two-three generation of Holocene terraces, only scarcely directly connected with the channel during large floods. According to the floodplain classification by Nanson, Croke (1992), it is a medium-energy non-cohesive floodplain with moderate resistance against erosion

\begin{tabular}{|c|c|c|c|c|}
\hline & \multirow{2}{*}{ Zone } & \multicolumn{2}{|c|}{ Altitude (m a.s.l.) } & \multirow{2}{*}{ Stream length $(\mathrm{m})$} \\
\hline & & beginning & ending & \\
\hline \multicolumn{5}{|c|}{ A. Source (headwater) zone } \\
\hline AS1 & High mountainous amphitheatric, cirque-spur type & 1,680 & 1,285 & 2,100 \\
\hline AS2 & $\begin{array}{l}\text { High mountainous through type with debris flow } \\
\text { and stepped valley bottom }\end{array}$ & 1,285 & 1,125 & 2,120 \\
\hline AS3 & $\begin{array}{l}\text { High mountainous breached moraine and debris- } \\
\text { flow cones type }\end{array}$ & 1,125 & 1,003 & 1,960 \\
\hline AS4 & High mountainous "V"-shaped valley type & 1,003 & 875 & 1,690 \\
\hline \multicolumn{5}{|c|}{ B. Transfer zone } \\
\hline BS1 & Foothill alluvial fan type & 875 & 700 & 4,870 \\
\hline $\mathrm{BS} 2$ & Hilly basin terraced valley type & 700 & 602 & 5,500 \\
\hline \multicolumn{5}{|c|}{ C. Response (depositional) zone } \\
\hline $\mathrm{CS} 1$ & Basin confluence fan type & 602 & 585 & 994 \\
\hline
\end{tabular}

Tab. 2: Selected zones and segments in the studied basin of the Smrečianka brook

\begin{tabular}{|l|c|c|c|c|c|c|c|c|}
\hline Segment & $\begin{array}{c}\text { Altitude } \\
\text { (m a.s.l.) }\end{array}$ & $\begin{array}{c}\text { Riverbed } \\
\text { average } \\
\text { angle (\%) }\end{array}$ & $\begin{array}{c}\text { Actual } \\
\text { length of } \\
\text { riverbed } \\
\mathbf{( m )}\end{array}$ & $\begin{array}{c}\text { Valley line } \\
\text { length (m) }\end{array}$ & $\begin{array}{c}\text { Degree of } \\
\text { sinuosity }\end{array}$ & $\begin{array}{c}\text { Valley } \\
\text { average } \\
\text { width (m) }\end{array}$ & $\begin{array}{c}\text { Riverbed } \\
\text { average } \\
\text { width (m) }\end{array}$ & $\begin{array}{c}\text { Degree } \\
\text { of valley } \\
\text { enclosure }\end{array}$ \\
\hline AS1 & $1,680-1,285$ & 18.81 & 27,100 & 1,955 & 1.07 & - & 1 & - \\
\hline AS2 & $1,285-1,125$ & 10.19 & 1,570 & 1,416 & 1.11 & 8 & 3 & 2.7 \\
\hline AS3 & $1,125-1,003$ & 7.22 & 1,690 & 1,450 & 1.17 & 35 & 5 & 7.0 \\
\hline AS4 & $1,003-875$ & 6.27 & 2,040 & 1,830 & 1.11 & 60 & 8 & 7.5 \\
\hline BS1 & $875-700$ & 3.59 & 4,870 & 4,380 & 1.11 & 160 & 8 & 20.0 \\
\hline BS2 & $700-602$ & 1.78 & 5,500 & 5,167 & 1.06 & 300 & 10 & 30.0 \\
\hline CS1 & $602-585$ & 1.71 & 994 & 947 & 1.05 & 1,200 & 30 & 40.0 \\
\hline
\end{tabular}

Tab. 3: Basic data on individual segments in the study area 
processes. Floodplain land cover is represented mostly by agricultural categories and urbanized areas. Only a narrow (up to $30 \mathrm{~m}$ ) riparian zone with willow trees is typical of the middle and upper part of this zone.

The response zone $(\mathrm{C})$ - in this zone, the medium energy non-cohesive floodplain becomes broader, forming an alluvial fan. The braided channel is completely channelized in this zone. The riparian zone consists of dykes covered by grass and dispersed willow shrubs.

\subsection{Segments}

When studying the segments in the study area, the main criterion was the presence of knickpoints along the stream longitudinal profile. Morphologically, their boundaries are defined by a quasi-homogenous slope of the riverbed, degree of channel confinement in the valley and channel sinuosity. The confinement of the channel in the valley was expressed by the ratio of the floodplain width to the watercourse channel width. The degree of sinuosity was expressed by the ratio of stream length to the length of the talweg.

Taking into account all the above-mentioned criteria and the shape of the valley cross-section, we distinguish the following segment types in the study area (Fig. 5). In the source zone (A), we distinguish 4 segments (AS1 to AS4), in the transfer zone (B) two segments (BS1 to BS2), and in the response zone (C) one segment (CS1). Their terminology and basic characteristics are summarised in Tabs. 2 and 3 (Tomčíková, 2008, Tomčíková, 2011).

High mountainous amphitheatric, cirque-spur type (AS1) is the highest segment of the study area. It is located in the source, glacially modelled part of the valley. The riverine landscape is limited to a narrow strip of the valley bottom without floodplain and without marked human activity. Slopes of the segment are almost continuously covered with coarse-grained material, consisting of crystalline complex, in which metamorphic rocks dominate over granitic rocks. Sediments from the Würm period consist of gravel and blocks of boulders. Water is practically motionless, stuck in ice and snow for most of the year. The frozen water absorbs more relief processes, and on the other hand it causes the mechanical destruction of sediments, leading to the enlargement of mantle rock, which is put into motion in the summer period through water or gravity (Figs. 6 and 7).

High mountainous through type with debris flow and stepped valley bottom (AS2) is composed of an asymmetric valley with slopes modelled by debris flows. This segment is typical of considerable relief steepness. In the slope direction, it has a convex shape. The bed is filled with boulder moraine sediments of the Würm. The sediments, namely boulders and cobbles, are not sorted. Rib structures are typical features of the channel. Dwarf pine is replaced by spruce here, whence the stream flows in a continuous spruce forest (Fig. 8 - see cover p. 2).

High mountainous breached moraine and debrisflow cones type (AS3) is typically broader with a developed riverbed and symmetrical valley slopes. The segment is situated on the border of an area, which had multiple glaciers in the Würm period. The rock outcrop in the channel is less frequent than in other

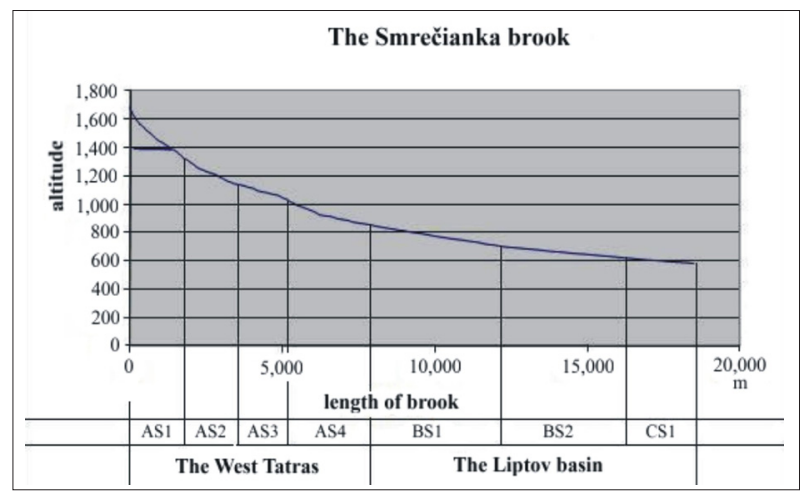

Fig. 4: The longitudinal stream profile of the Smrečianka brook (after Tomčíková, 2008, 2011 modified)

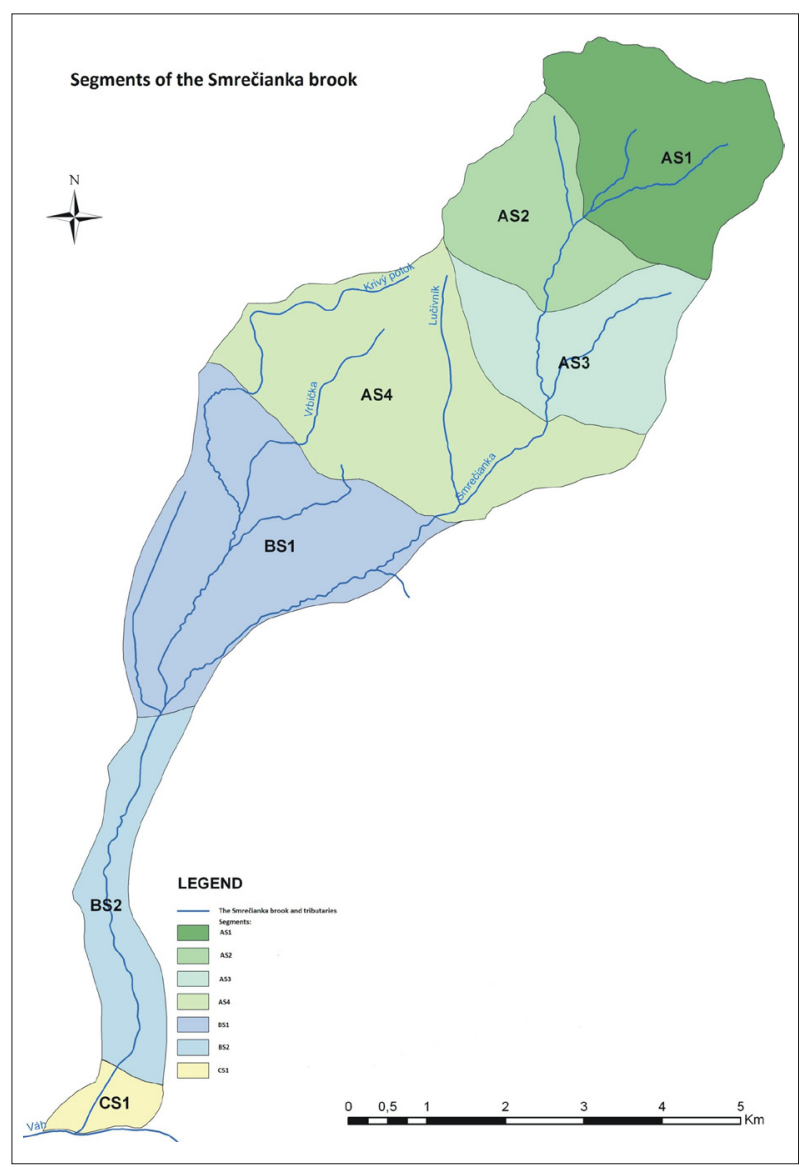

Fig. 5: Segments of the Smrečianka brook (after Tomčíková, 2011) 


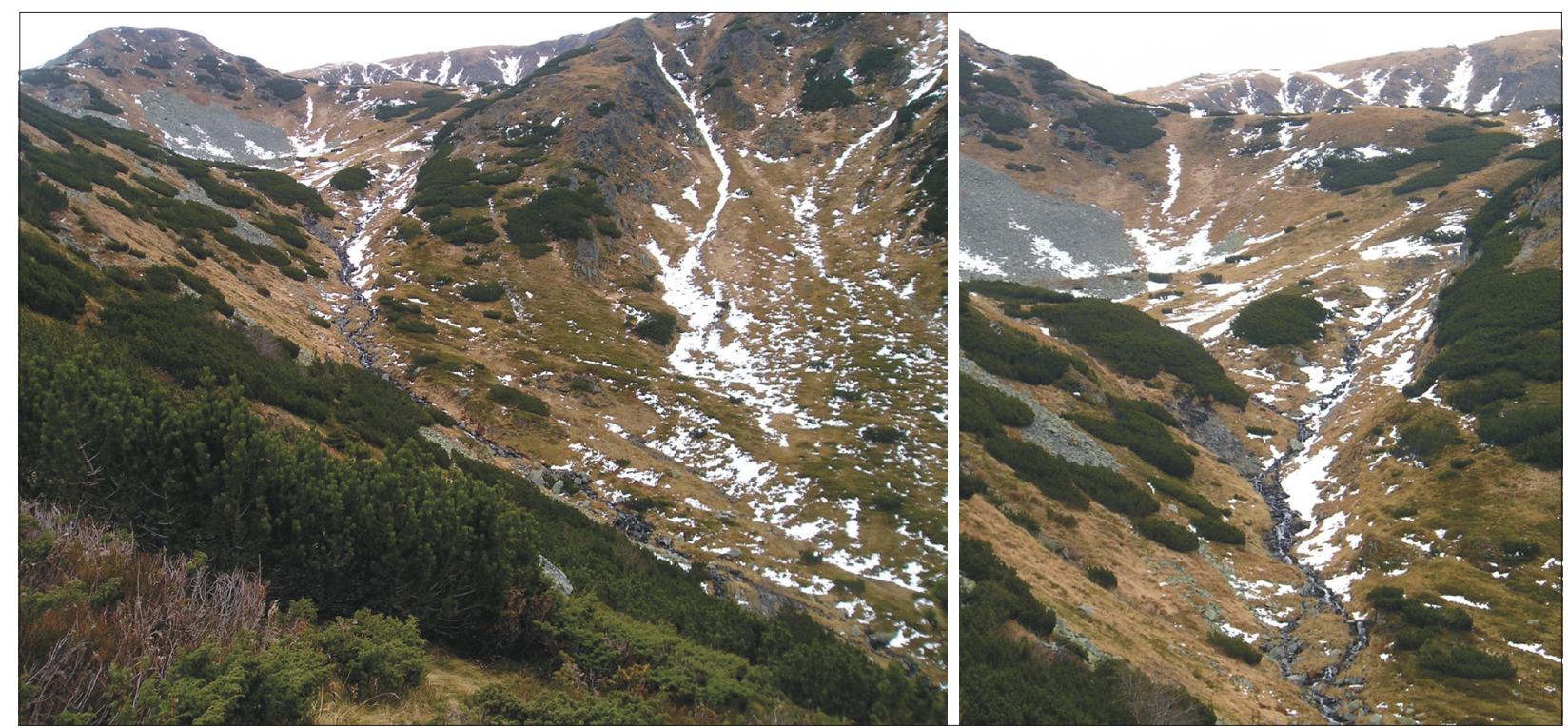

Figs. 6 (left) and 7 (right): AS1 type segment of Smrečianka brook / AS1 type segment (close-up)

(Photo I. Tomčíková, 2011)

parts of the valley; it is covered by glacial and glaciofluvial material and deluvial deposits. The riverbed is filled with the moraine sediments of the Würm period, with a greater content of fragments, which formed the frontal moraine. The Würm sediments are significantly washed up and also joined with the side valley. The mass-movement of weathering products on the slope dominated, and the water falls through steep rock walls in the form of a cascade. It is identified on the lateral profile by a gentle curve in the upper part and by a steep curve in the lower part (Fig. 9).

High mountainous "V" shaped valley type (AS4) is situated in the area stretching from the altitude of $1,003 \mathrm{~m}$ a.s.l. (wooden bridge) up to the end of the valley and its transition into the Liptov basin. The dominant geomorphological process is fluvial modelling present in the channel pattern; the processes of slope modelling on the valley side slopes are less prominent. The segment is situated outside the area modelled by Würm glaciers. The relative altitude of the slopes is lower as compared with the previous segment, and the floodplain is clearly developed. The single cascade and step-pool reaches alternate with the bifurcated rapids. Channel islands are mostly covered by trees. Longitudinally, avulsions typically occur at reaches marked by the lower degree of inclination. The floodplain is characterized by great energy, mostly built by sediments composed of cobbles, pebbles and sand. There is an asphalt road leading to the Žiarska Chalet built on the top of it. The landscape is covered by spruce forest (Fig. 10).

Foothill alluvial fan type (BS1) follows on the AS4 segment as early as in the Liptovská hollow basin. From the longitudinal profile curve, it is difficult to identify the start of this segment, since in the upper part it is similar to the previous segment. Its identification is however clearly determined by the morphogenetically distinctly developed fan at the foot of the mountain range. The slope is gradual; therefore, the boundary with the BS2 segment is not evident, either. The front of the fan is situated on the transfer of the mountain into the basin, with the villages of Žiar and Smrečany being situated at its tail. On the border with the hills, the stream used to be bifurcated in the past; today it is a single channel with a rapids character. In many locations, a sharp contact of the channel with the terrace (abut) is evident. Material in the channel consists of larger cobbles and boulders, upper layers of the floodplain are composed of fine-grained pebbles (Tomčíková, 2011).

The river landscape of the Smrečianka brook in the segment is markedly influenced by human activities. At the head of the alluvial fan, there are hotels, company chalets and resorts with individual houses and objects. Human activity is especially evident in the villages of Žiar and Smrečany, but also in their surroundings. There are meadows and pastures in the floodplain. Meadows are predominant, which are alternatively used for pasture and for agriculture. Wet meadows are covered by high grass that is valuable as fodder. Pastures are used for cattle and sheep alike. In Smrečany, a small dam in the form of a polder was built for retaining the flood waters. The dam disrupts the river continuum and impacts the free passage of fish. Following the dam, the riverbed has been regulated up to its confluence with the tributaries of Vrbička, Trstie and a small affluent on the left side. The village of Žiar borders the village of Smrečany on the south. These two villages are joined, giving the impression of being just one village. The village used to have a water mill 
with the mill canal, but it was destroyed by flood in 1948. The only thing that remained was the canal, as a tributary of the Smrečianka (Fig. 11).

Hilly basin, terraced valley type (BS2) stretches from Smrečany up to the housing estate named Podbreziny. The channel of Smrečianka is asymmetrically (to the right side) localised in its floodplain and fully regulated throughout the segment. Small check-dams built in the channel mediate and slow down the down- slope transit of sediments. The banks are reinforced by willow trees, which form a continuous riparian zone. The sinuosity index is low.

Downstream of the segment, on the young Holocene terrace, Vitálišovce, a municipality of Liptovský Mikulás is situated, followed by the largest housing estate of Liptovský Mikuláš - Podbreziny. Vitálišovce is situated in the floodplain on the left at an altitude of $620 \mathrm{~m}$ a.s.l. It used to be an integral part of the

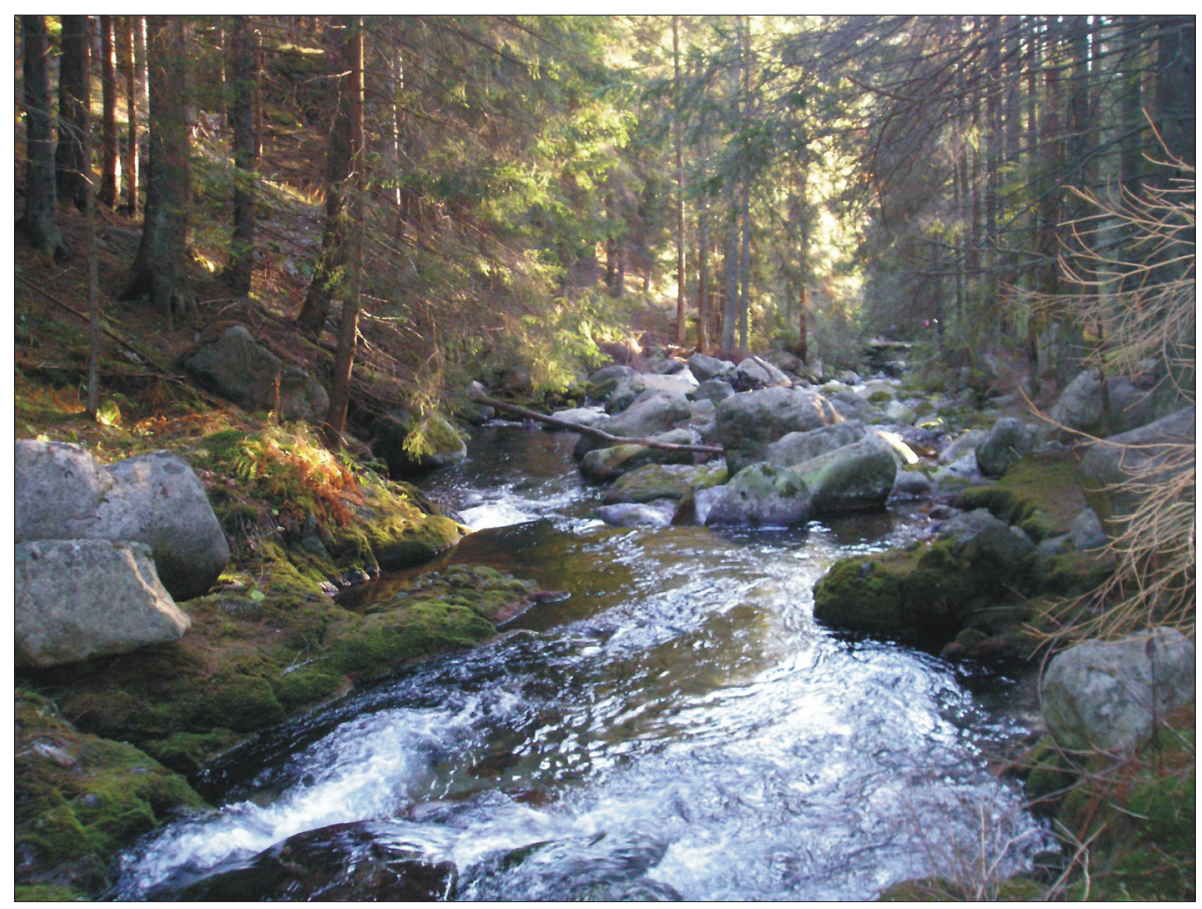

Fig. 9: AS3 type segment of the Smrečianka brook (Photo: I. Tomčíková)

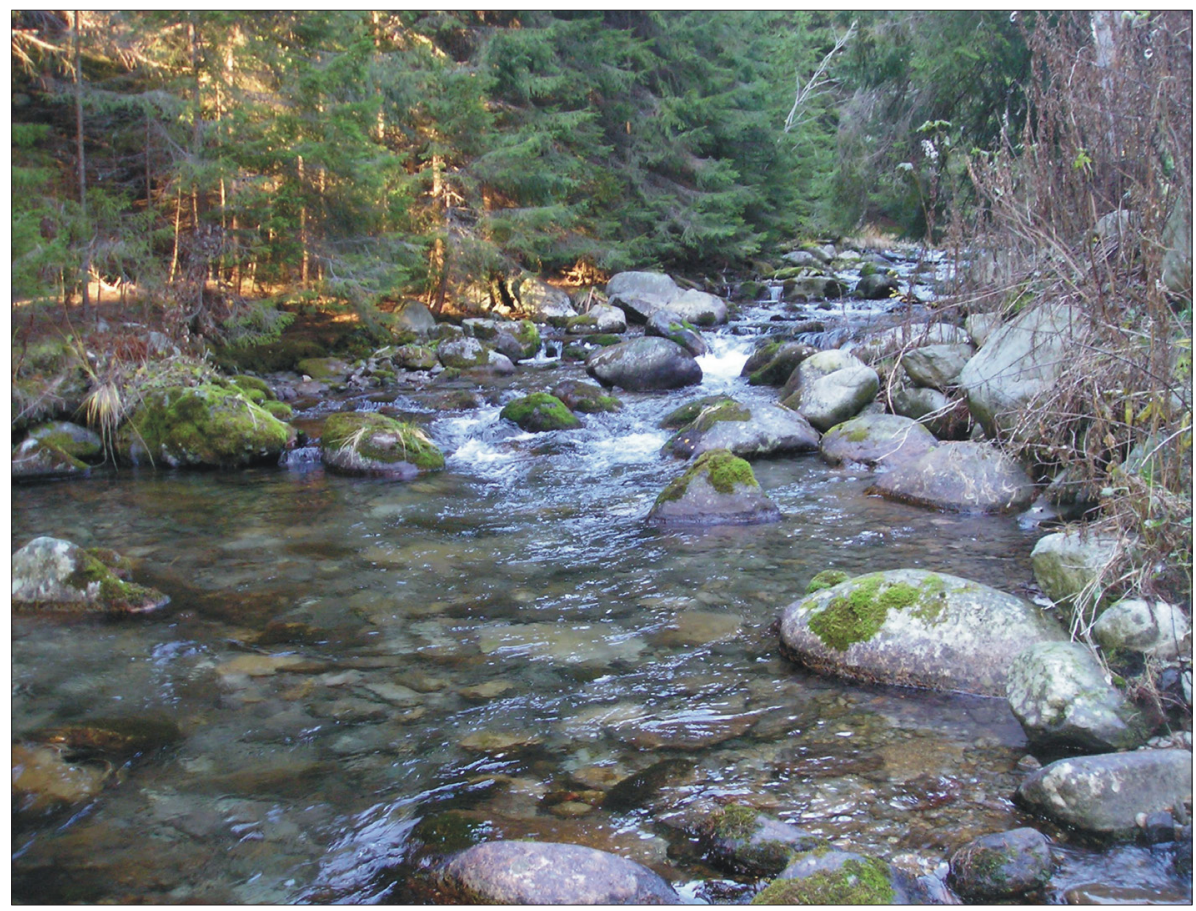

Fig. 10: AS4 type segment of the Smrečianka brook (Photo: I. Tomčíková, 2011) 
village Okoličné. In the 1970s, it became an integral part of Liptovský Mikuláš. In 2006, the village population was 106 persons. In the 1980s, the housing estate Podbreziny was built along the channel downstream Vitálišovce in lengths of approximately $1 \mathrm{~km}$, which became the largest housing estate of Liptovský Mikuláš. The present population is around 10,000 people, who live in 54 blocks of flats. The Smrečianka River divides this housing estate into two parts (eastern and western). The left part is situated on the left bank of the stream; it is densely built-up with old blocks of flats, a stadium, supermarket and shops. A road is built at the contact of the floodplain with the terrace, leading toward Smrečany, Žiar and the Žiarska Valley. The newly-built blocks of flats - an old people's home and the centre for social services, are on the right bank. The western part of the river landscape is abutted with the segmented slope of Háj-Nicovô hill, which is partly forested and partly covered by bushes (Fig. 12).

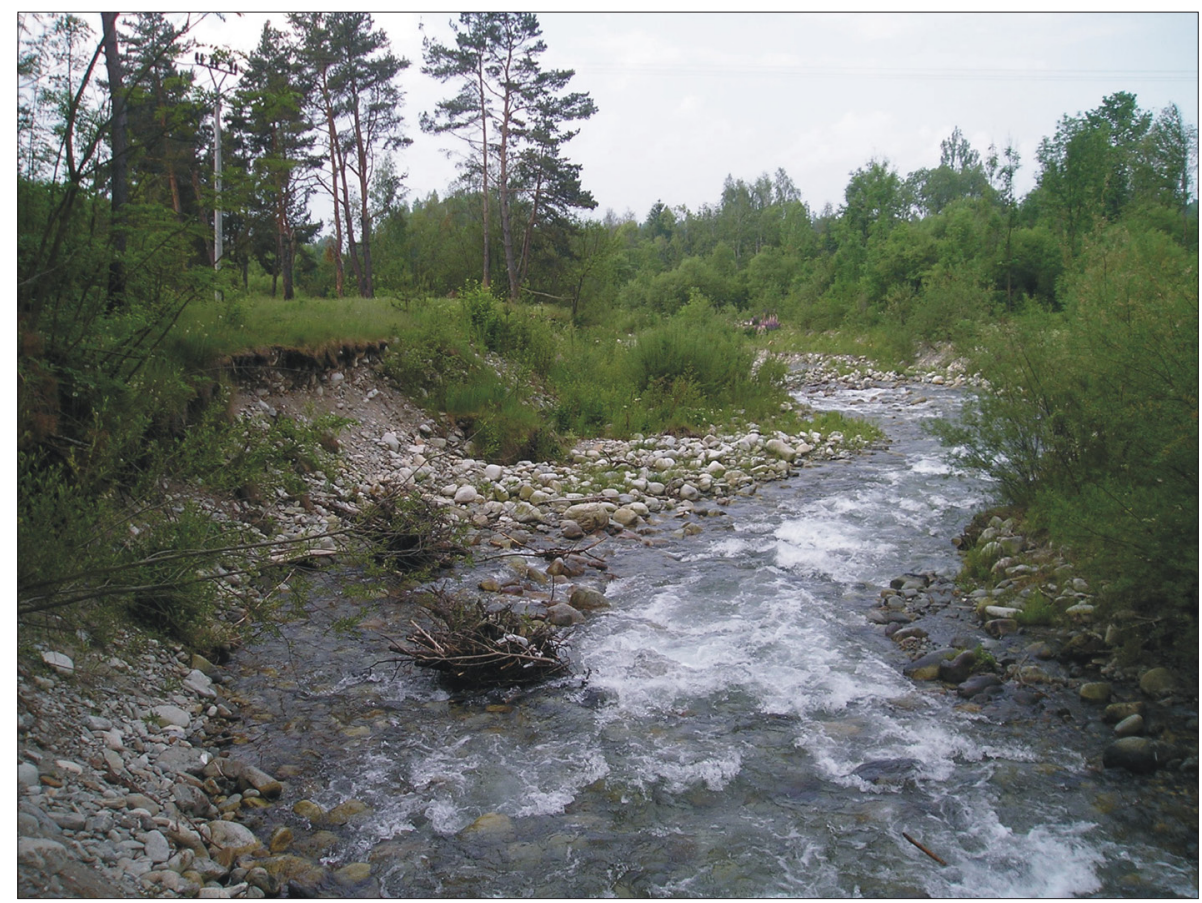

Fig. 11: BS1 type segment of the Smrečianka brook (Tomčíková, 2011)

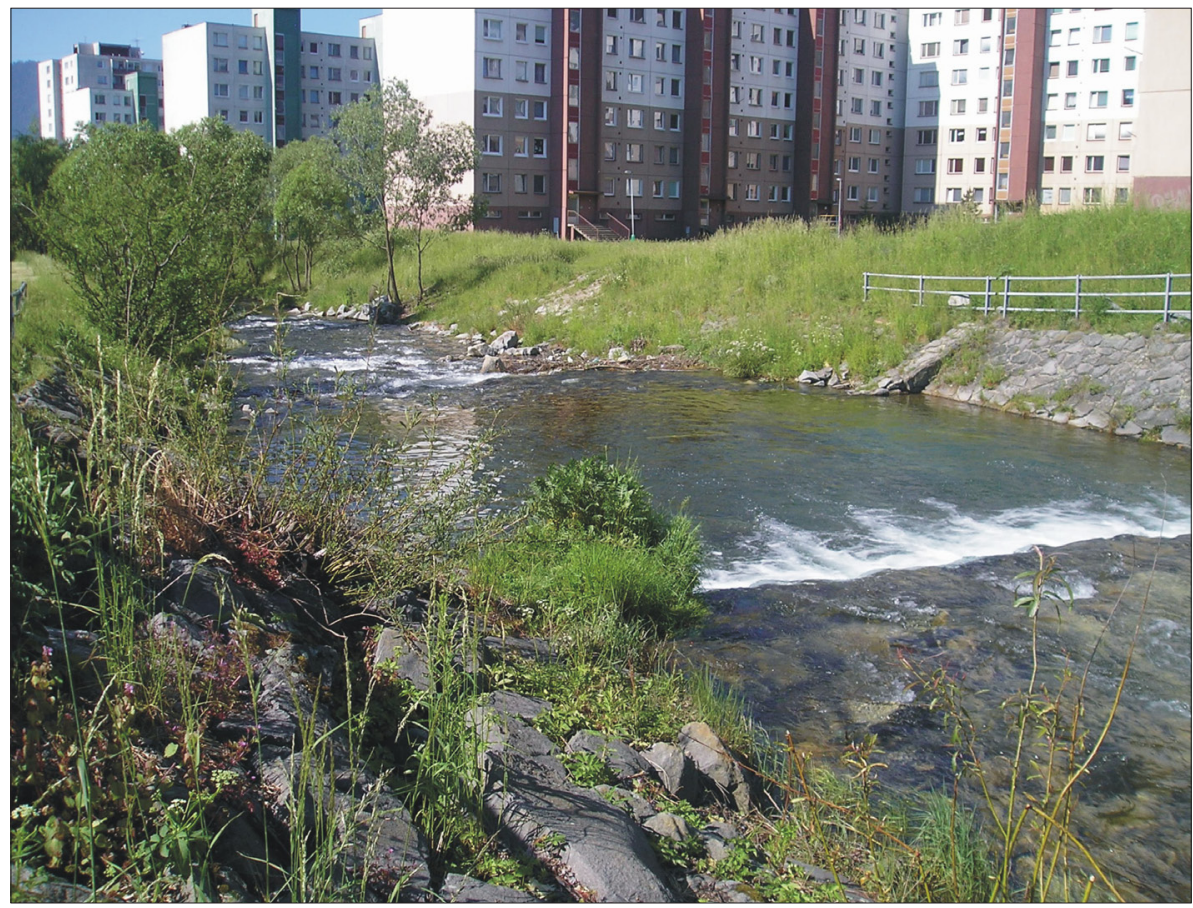

Fig. 12: BS2 type segment of the Smrečianka brook (Photo: I. Tomčíková) 
Basin confluence fan type (CS1) is the only segment of the response zone in the Smrečianka riverine landscape. In morphological and genetic terms, it is linked to the development of the Váh River floodplain, into which it gradually enters. The alluvial fan of the Smrečianka brook transforms into a low terrace of the Váh R. (T-Ib) at a relative elevation of 2-3 $\mathrm{m}$ above the channel water level; the surface is inundated only during catastrophic floods (Droppa, 1964). The thickness of sediments in the floodplain varies from 4 to $9 \mathrm{~m}$. According to the channel planform classification system (Nanson, Knighton, 1996), Smrečianka represents in this segment a laterally inactive slightly braided channel, rarely diverging by islands. Central bars, reinforced by the tree vegetation (especially young willow trees), are frequent here. The riverbed material is composed of fine up to rough gravel and cobbles of various sizes. The riverbed is channelized by duplex dams for the flow volume of $Q_{100}=93.0 \mathrm{~m}^{3} \cdot \mathrm{s}^{-1}$.

The built-up area of Okoličné village as a municipal district of Liptovský Mikuláš, with some 1,196 inhabitants as of 1 April 2006, is situated in the floodplain. The village was affected by a disastrous flood in 1812. The flood wave carried away a number of houses and severely damaged the church and the monastery. Okoličné merged with Liptovský Mikuláš in 1971 (Fig. 13 - see cover p. 2).

\section{Conclusion}

Rivers are natural hierarchical systems that can be resolved into different levels of organization. A level, taxon, or holon, is a discrete unit of the level above and an agglomeration of discrete units from the level below, in the conceptual model of River Landscape
Hierarchical Classification. At higher hierarchical levels, the process is slower or of lower frequency, and the reactions are therefore slower than at lower levels.

Studying the riverine landscape as a holistic and hierarchical spatial structure contributes to the knowledge and understanding of mutual relations among the parts of this complex system, and at the same time creates a basis for its sustainable development.

Since this kind of research has been launched only very recently in Slovak geography and in landscape ecology, this paper represents a case of river research oriented towards the presentation of holistic perceptions and knowledge of riverine landscapes, exemplified by the riverine landscape of the Smrečianka brook.

From the top to the bottom, we identified three taxa in the riverine landscape of the Smrečianka brook. These zones are singled out in accordance with seven taxa of the hierarchical model of riverine landscape morphology, together with the classification of zones based on Lehotský, Novotný (2004). Regarding the basic criteria of river system longitudinal connectivity, we distinguish these three main zones - the source (headwater) zone in the Žiarska dolina Valley, the transfer zone in the Liptovská Basin, in the part called the Smrečianska Upland, and the response (depositional) zone - in the part called the Liptovská Floodplain, where it flows into the Váh River.

\section{Acknowledgement}

The author would like to thank sincerely an anonymous reviewer, whose comments significantly contributed to the improvement of the manuscript.

\section{References:}

ADÁMYOVÁ, S. (1989): Dlhodobé ročné prietoky, ich územná a časová premenlivost'. Zborník prác SHMÚ, 29/II, p. 30.

DROPPA, A. (1964): Výskum terás Váhu v strednej časti Liptovskej kotliny. Geografický časopis, Vol. 16, No. 4, p. 313-325.

GREŠKOVÁ, A., LEHOTSKÝ, M. (2004): Priestorové štruktúry riečnej krajiny. Zborník z konferencie Říční krajina, Palackého univerzita, Olomouc, p. 44-51.

LEHOTSKÝ, M. (2004): River Morphology hierarchical Classification (RMHC). Praha, Acta Univeristatis Carolinae, Geographica, XXXIX, No. 1, p. 33-45.

LEHOTSKÝ, M. (2005): Riečna krajina - základné koncepty. ALFA SPECTRA STÚ, Urbanistické listy FA STÚ, p. 38-46.

LEHOTSKÝ, M. (2006): Riečna krajina a jej udržatel'ný rozvoj - nová oblast' aplikácie integrovaného prístupu, In.: IZAKOVIČOVÁ, Z.: Smolenická výzva III, Smolenice 18.-19. apríl 2006, Bratislava: Ústav krajinnej ekológie, p. $155-159$.

LEHOTSKÝ, M., GREŠKOVÁ, A. (2003): Geomorphology, fluvial geosystems and riverine landscape (methodological aspects). Geomorphologia Slovaca, No. 2, p. 46-59.

LEHOTSKÝ, M., LACIKA, J. (2007): Typy segmentov dolinovo-riečnych systémov s vel’vysočinovou zdrojovou zónou: príklad Tatier. Geomorphologia Slovaca et Bohemica Vol. 7, No. 1, p. 27-35.

LEHOTSKÝ, M., NOVOTNÝ, J. (2004): Morfologické zóny vodných tokov Slovenska. Geomorphologia Slovaca, No. 2, p. 48-53. MILLER, G. T. (1990): Living in the Environment: An Introduction to Environmental Science. Wadsworth Publishing, Belmont, 60 pp. 
NANSON, G. C.,CROKE, J. C. (1992): A genetic cassification of floodplains. Geomorphology, Vol. 4, p. 459-486.

NANSON, G. C., KNIGHTON, A. D. (1996): Anabranching rivers: their cause, character and classification. Earth Surface Processes and Landforms, Vol. 21, p. 217-239.

POOL, G. C. (2002): Fluvial landscape ecology: addressing uniqueness within the river discontinuum. Freshwater Biology, Vol. 47, p. 641-660.

SCHUMM, S. A. (1977): The fluvial system. Wiley-Interscience, Chichester. 338 pp.

TOMČÍKOVÁ, I. (2008): Priestorová variabilita morfológie bystrinného vodného toku. Geomorphologia Slovaca at Bohemica Vol. 8, No. 2, p. 58-68.

TOMČÍKOVÁ, I. (2011): Štruktúra riečnej krajiny Smrečianky. VERBUM Ružomberok, 160 p.

WADESON, R. A., ROWNTREE K. E. (1998): Application of the hydraulic biotope concept to the classification of instream habitats. Aquatic Ecosystem Health and Management, Vol. 1, No. 2, p. 143-157.

\section{Author's address:}

RNDr. Ivana TOMČÍKOVÁ, Ph.D.

Department of Geography, Faculty of Education, Catholic University in Ružomberok Hrabovská cesta 1, 03401 Ružomberok, Slovak Republic e-mail: ivana.tomcikova@ku.sk

Initial submission 28 December 2012, final acceptance 26 September 2013

Please cite this article as:

TOMČÍKOVÁ, I. (2013): Zones and segments as taxa used in the hierarchical classification of riverine landscapes: A case study of the Smrečianka brook, Slovak republic. Moravian Geographical Reports, Vol. 21, No. 4, p. 27-37, DOI: 10.2478/mgr-2013-0018. 